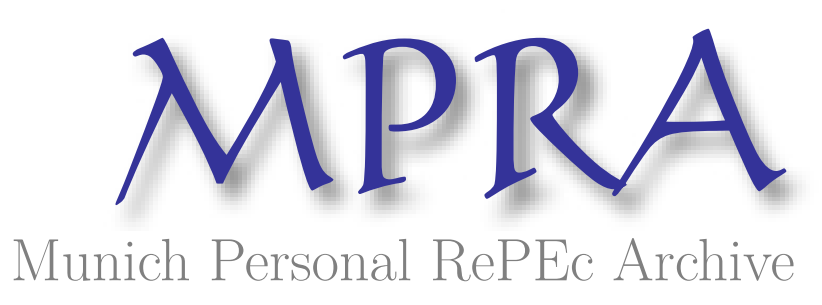

Coordination Failures, Cluster Theory
and Entrepreneurship: A Critical View

Glavan, Bogdan

May 2007

Online at https://mpra.ub.uni-muenchen.de/6033/

MPRA Paper No. 6033, posted 30 Nov 2007 17:01 UTC 


\title{
COORDINATION FAILURES, CLUSTER THEORY AND ENTREPRENEURSHIP: A CRITICAL VIEW
}

\author{
Bogdan Glăvan*
}

\section{Introduction}

Development policy has been energized in the last decades by a number of contributions emphasizing a new positive role the state can and should play in fostering economic growth. The central pillar of this literature is Michael Porter and his theory of clusters. In a few words, a cluster is a bundle of industries that gain in efficiency through co-location. After the publication of Porter (1990), this author has quickly become the foremost advocate of industrial policy of our times, arguing that clusters should be central to any competitiveness agenda. Porter's influence is phenomenal throughout the world. ${ }^{1}$ $\mathrm{He}$ is a "guru" of economic development, "spiritual father" of numerous research institutes, cluster initiatives and projects, and advisor for economic development policy in many countries. In Europe in particular, where governments are more prone to a centralized development strategy, clusters have become increasingly an objective of economic policy. ${ }^{2}$

The cluster theory - reflecting the professional formation if its author as management strategist - underlines the gains expected to accrue from the regional concentration of related industries and makes the normative statement that governments should boost the development of clusters. Whatever its influence on policymakers across the world, the theory lacked any positive explanation about the necessity of government

\footnotetext{
* Bogdan Glăvan is Assistant Professor of economics at the Romanian American University in Bucharest.

${ }^{1}$ Witness the hundreds of scholarly articles on clusters written in the last years. See Maskell and Kebir (2005, p. 2) for accurate numbers on this matter.

${ }^{2}$ See European Commission (2002; 2003). For a detailed presentation of how cluster ideology permeated current economic policies in Central and Eastern European countries, see IRE (2005). For example, the most famous cluster in the world, Sillicon Valley, has inspired the establishment of many "Valleys" in european countries: Motorsport Valley in the U.K., Paris Optics Valley in France, DSP Valley in Belgium, Dommel Valley in the Netherland, Materials Valley in Germany, Dalarna Crystal Valley in Sweden, Medicon Valley in Denmark and others. (Solvell et al., 2003, p. 16)
} 
intervention in the natural functioning of the market. ${ }^{3}$ Emphasizing the merits of industrial agglomeration, it did not provided an answer to the essential question: could not these benefits be obtained on a free market, in the absence of any interference of the government? Does the potential existence of cluster benefits validate the common sugestion that countries should promote regional development through cluster policies?

A number of economists have attempted to anchor the appetite for clustering initiatives in solid theoretical bedrock. They have pointed out an interesting market failure that may prevent the emergence of profitable clusters and thus jeopardize overall economic development: the failure of individuals to coordinate changes in their actions in order to reap the benefits of a better situation. ${ }^{4}$ Although the literature on coordination problems has a long tradition, ${ }^{5}$ only recently it has become concerned with the relation between this supposed type of market failure and the alleged benefits of industrial agglomeration. Economists like Rodrik (2004) and Rodriguez-Clare (2005a; 2005b) have used this particular market failure argument as justification for a porterian-style "new industrial policy", the goal of which is to induce entrepreneurs to invest in those projects with the highest social return.

As the coordination externality argument goes, many investment projects require simultaneous investments in complementary production processes. Firms can improve their performance if entrepreneurs realize that their individual success is dependent on the actions of other market participants. They can get organized to identify common challenges, for example that all companies would profit from a specific training program at the local university, from an investment in improving transport facilities, or from a joint effort to upgrade the local power or water supply. For an individual company it would not make sense to address such issues but for the group as a whole they become hugely beneficial efforts. Put it differently, the social rate of return on investments in key projects is higher than the pure private return. This means that coordination will be

\footnotetext{
3 "Broadly speaking, the arguments for cluster policy, i.e. intervention by government or other public actors in regard to the development of clusters, are not yet fully-established." (Ketels 2005, p. 8)

${ }^{4}$ Ferris and Gawande (1998) attempt to provide evidence for this argument, referring to the case of developing countries.

${ }^{5}$ A pertinent review of the literature on coordination failure can be found in Hoff (2000) and Hoff and Stiglitz (2001).
} 
under-supplied and that government should correct market failure, providing proper incentives in order to reach the optimal level of coordination.

This paper intends to provide a refutation of the idea that coordination failures as manifested in the inability of clusters to emerge can serve as a ground for government intervention. It uses mainly Porter, Rodrik and Rodriguez-Clare thesis as an example of this approach and criticizes the claim that coordination externalities prevent the market process to allocate resources optimally. In our view, such an essay is important given that in the last years the experimentation of various cluster policies has intensified considerably. Indeed, one grave lesson that can be drawn from the existing literature on clusters is that discussion of alternative cluster policies has eclipsed the cluster theory. People stopped asking questions about the meaning of cluster and started to exercise various cluster policies instead.

The paper is organized as follows. The next section describes the coordination failure argument which pushes the case for industrial policy, with a focus on the relation between coordination problems and Porter's theory of clusters. Section three presents the policy prescriptions advanced in the new development economics literature. Section four provides a critical analysis of the coordination failure-based development economics. It explains at the outset the role of entrepreneurs in achieving coordination on a free market. Then, it criticizes the notion of coordination failure and underscores the weaknesses of cluster theory, explaining the risks associated with attempts to build clusters. Section six explains why the new argument of market imperfection fails to support the case for industrial policy. The last section concludes the paper.

\section{From coordination failure to cluster policy}

As Anderson et al. (2004, pp. 48-49) acknowledges, the foremost motive for pursuing cluster policies derives from a supposed market failure in achieving economic coordination. The best explanation of this market failure is provided by Rodriguez-Clare (2005) and Rodrik (2004). The former author (p. 3) points out the fact that the success or failure of an action depends upon the context in which it is undertaken: "A firm's productivity depends not only on its own efforts and abilities, and on general economic 
conditions (e.g., the macroeconomic environment and the legal system), but also on the actions of other firms, infrastructure, regulation and other public goods".

On a more specific note, Rodrik (pp. 12-13) notes that

"Many projects require simultaneous, large-scale investments to be made in order to become profitable. [...] An individual producer contemplating whether to invest in a greenhouse needs to know that there is an electrical grid he can access nearby, irrigation is available, the logistics and transport networks are in place, qurantine and other public health measures have been taken to protect his plants from his neighbors' pests, and his country has been marketed abroad as a dependable supplier of highquality orchids. All of these services have high fixed costs, and are unlikely to be provided by private entities unless they have an assurance that there will be enough greenhouses to demand their services in the first place. This is a classic coordination problem. [...] More generally, coordination failures can arise whenever new industries exhibit scale economies and some of the inputs are non-tradable (or require geographic proximity)."

The attempt to relate the observation that any action's result depends on the specific environment in which it is performed to the theory of externalities is problematic. As we will try to demonstrate, interpreting the coordination problem in the light of externalities theory is questionable. Potential weaknesses in the argumentation can pave the ground for mistaken policy recommendations. Before checking the line of reasoning for errors it is necessary to put the issue in a proper perspective.

As Howitt (2001, pp. 3-4) argues, the coordination effort market participants put depends critically on their expectation that other individuals will act to take full advantage of potential gains from trade: "When people on one side of a market put more effort into the matching process, this makes it more worthwhile for those on the other side to do the same thing, because it makes transacting less costly for them." For example, pessimistic expectations on the part of firms that they can find appropriate workers will make more costly for workers to find suitable jobs. A vicious circle seems to ensue, keeping the market at distance from an efficient allocation of resources. 
Following a similar line of reasoning, Marshall (p. 13-14) provides a good explanation of what is meant by coordination failure:

"Suppose the economic performance of a country (or a firm, industry, or financial market) depends on large numbers of investors being willing to provide funds. If it is generally believed that other investors will withhold funds, it is rational for any given investor to refrain from investing. Thus, these beliefs become self-fulfilling. This represents a coordination failure because everyone would be better off if all investors provided funds to the affected country. Unfortunately, there is no way to coordinate investor actions in this way."

More precisely, under the circumstances described above, there are multiple equilibria: a good equilibrium, obtained when entrepreneurs have optimistic expectations and thus manage to coordinate their businesses, and a bad equilibrium, resulting from entrepreneurs' reluctance to invest and their failure to coordinate. When the market mechanism does not work, the government should coordinate (stimulate) entrepreneurs into the good equilibrium.

This policy prescription echoes the arguments of Rosenstein-Rodan (1943) and Hirschman (1958) who argued for the necessity of a massive and concentrated industrialization policy ("big push" strategy) in order to break the underdevelopment equilibria. In light of the negative consequences of industrialization policy carried out by many developing countries in the 1960s and 1960s, market failure theorists are cautious, and insist that the solution requires skill rather than resources (Hoff, 2000). Essentially, the government should adopt policies that rein in the spillovers among entrepreneurs, paving the way for the good equilibrium. Since many spillovers are local in nature, geographical considerations should play an important role in the political recipe.

The coordination externality argument can be associated with Porter's (1990; $1998 \mathrm{a} ; 1998 \mathrm{~b} ; 2000)$ idea that clusters, that is, regionally coordinated industries, are critical for overall economic growth. ${ }^{6}$ Clusters are defined as collection of related

\footnotetext{
${ }^{6}$ As Rodrik (2004, p. 13) put it, "the cluster approach to development represents a narrower version of the same idea." See also Rodriguez-Clare (2005).
} 
activities and industries that have managed to overcome the problem of coordination. ${ }^{7}$ "As the cluster develops it becomes a mutually reinforcing system where benefits flow backwards and forwards throughout the industries in the cluster." (LeVeen, 1998).

Clusters arise because companies are stimulated to locate near one another to take advantage from the existence of a variety of external effects. The literature emphasizing these externalities is considerable. ${ }^{8}$ The basic reason for clustering is the minimization of transportation and communication costs. Also, geographical proximity gives companies the possibility to access a large pool of suppliers (including skilled workforce) and thus reduce search costs, which positively impacts productivity. In addition, industrial agglomeration facilitates the flow of tacit knowledge among firms (Desrochers, 2001), creating an "environment of learning", and allowing companies to more efficiently acquire "know-how" and accelerate innovation. More generally, "agglomeration fundamentally serves to increase the opportunities for exchange and to reduce the incidence of missing markets" (Gordon and McCann, 2000, p. 518). ${ }^{9}$ This perspective is supported by Porter (1998), who argued that "being part of a cluster allows companies to operate more productively in sourcing inputs; accessing information, technology, and needed institutions; coordinating with related companies; and measuring and motivating improvement."

The normative implication of the agglomeration effects argument is that the state should promote the formation of clusters. In Porter's view, "clusters should represent an important component of state and local economic policy" (Porter 2000, p. 29.). Alternatively, one can use cluster-based policy as a tool to remove the imperfections of the free market by facilitating the coordination of economic agents: "Clusters provide opportunities for microeconomic interventions that promote coordination" (RodriguezClare 2005, p. 3). Consequently, the government should promote the development of

\footnotetext{
${ }^{7}$ See Rodriguez-Clare (2005, p. 10). Porter (1998, p. 226) holds a slightly different definition: "a cluster is a form of network that occurs within a geographical location, in which the proximity of firms and institutions ensures certain forms of commonality and increases the frequency and impact of interactions".

${ }^{8}$ For a review, see Gordon and McCann (2000), Sautet (2002, pp. 42-57), Andersson et al. (2004, pp. 1517) and Chapman (2005, pp. 598-600).

${ }^{9}$ See also Feldman, Francis and Bercovitz (2005, p. 131). According to sociologists, clusters creates a social network, facilitating interactions among firms, as well as interpersonal relationships, and building up a "social capital" which enhances further the competitiveness of cluster members.
} 
clusters by inducing entrepreneurs to invest in those projects that offer high spillover effects.

This new ground for industrial policy has found an increasing number of supporters among policymakers throughout the world. According to Danson and Whittam (1999), "Many areas around the developed world are adopting the clusters approach to regional economic regeneration, with the United Kingdom-wide government Department of Trade and Industry suggesting that this could be a key element in re-establishing the competitiveness of national businesses in the future."

At the present, the opinion that clusters can play an important role in fostering industrial development is widely held among development strategists and government consultants. ${ }^{10}$ All international economic organizations - OECD, the World Bank, IMF, UNIDO and UNCTAD - are engaged in sponsoring research, evaluation and development of cluster or cluster policies throughout the world. ${ }^{11}$ Under the label of "cluster policy" public authorities actively encouraged the establishment of "science parks", "business incubators", "(eco-)industrial parks", "industrial districts", "targeted recruitment", "enterprise zones", "foreign trade zones", "centers of expertise", and a large variety of other economic experiments designed to enhance industrial concentration and cooperation.

\section{Coordination and government intervention}

How is government supposed to improve the coordination of market participants? As Rodriguez-Clare (2005, p. 30) argues, "One interesting approach would be for the government to create a mechanism whereby business associations representing different clusters would submit proposals that identify areas for collective action and public support. The different proposals would be reviewed by a "panel of experts," who would rank them according to the estimated social return for the public investment. Finally, the best projects would be selected for support."

\footnotetext{
${ }^{10}$ See, for example, Nadvi and Barrientos (2004).

${ }^{11}$ See, for example, Feser (2002); Roelandt and Hertog (1999); UNIDO (2001); UNCTAD (2002).
} 
The proponents of the new industrial policy are aware that past interventionism has failed systematically to promote growth and prosperity all over the world, and they are very cautious to differentiate their opinions about market failure from the older view of government's superiority. ${ }^{12}$ Porter (2000, p. 27) argues that "a role for government cluster development and upgrading should not be confused with the notion of industrial policy" and that "the intellectual foundations of cluster theory and industrial policy are fundamentally different, as are their implications for government policy." RodriguezClare (2005, p. 29-30) holds a similar opinion, maintaining that "if one wanted to call the current proposal a sort of industrial policy, it would be a "soft" industrial policy, rather than the "hard" industrial policy implemented in previous decades, which entailed distorting prices so as to reallocate resources to certain sectors as a way to generate a new pattern of comparative advantage [...] This is important because soft policies are likely to be more transparent and less costly." Likewise, referring to the manner in which various industrial projects are to be evaluated by government officials, Rodrik (2004, p. 27) appreciates that "Proposals need to be made public, formally analyzed and evaluated by technocrats, and their fiscal impact costed out."

According to the proponents of the new industrial policy, the government should shift the attention from individual firms and industries to clusters. Rodriguez-Clare (2005, p. 28) points out that unlike the old strategy, which attempted to pick winners (that is, individual companies), "policy should pick clusters", and Porter complements this arguing that instead of targeting specific clusters, all existing and emerging clusters deserve attention.

In spite of its popularity among economists and policymakers, the case for the new industrial policy cannot be taken for granted. In particular, the idea that interdependencies among market participants prevent an optimal allocation of resources, as well as the policy recommendation based on it, should be considered carefully.

\section{Issues to consider with cluster theory}

\footnotetext{
${ }^{12}$ As Rodriguez-Clare (2005, p. 29) mentions, "there is no need for the government to distort prices so as to reallocate resources towards certain sectors."
} 
A number of considerations prompt us to claim that coordination-based model of market failure in development does not enrich the understanding of how entrepreneurship contributes to development, is unrealistic and internally inconsistent. In what follows, we will analyze some of its weaknesses closely.

\subsection{Entrepreneurship and coordination}

The proponents of coordination failure argument provide a very simple definition of coordination. In their view, coordination problems typically arise when "profitable new industries fail to develop unless upstream and downstream investments are coaxed simultaneously" (Rodrik 2004, p. 13). For example, "building an airport in a region that has no hotels would not lead to any traffic, but hotels without a regional airport may not be profitable either" (Rodriguez-Clare, 2005, p. 10).

This view of coordination may be considered as simply a truism. If a successful investment occurs, it is profitable because it is properly integrated into a network of complementary businesses. Inversely, any investment failure brings a loss because it does not fit in a suitable network of complementary businesses.

In this perspective, coordination is conceived as a technological problem. Coordination is achieved whenever a group of complementary investments are set up simultaneously. But technological complementarity does not lead automatically to economic efficiency. Usually, there are several (possibly many) technological possibilities of producing a given good, and a lot more possibilities of producing complementary goods. To take the above-mentioned example, various types of hotels operate with various degrees of profitability if transportation is available via railroad, highway or airport. And one cannot predict that simultaneous investments in building hotels and transportation will be profitable.

Alternatively, coordination can be viewed not as a problem of technical complementarity/compatibility between different economic units, or as a problem of synchronization of producers, but as a relation between producers and consumers. Following Mises (1998), we should consider coordination as the result of entrepreneurial actions. The market process effectively coordinates productive efforts because the 
structure of prices is shaped according to the relative importance of resources for their final users - the consumers. ${ }^{13}$ More precisely, by forecasting future market conditions, entrepreneurs bid for resources in an attempt to increase investments in those production processes with the highest expected rate of return, that is, resulting in the output of those goods consumers need most. Thus, because the prices for factors of production are continuously adjusted to the expected prices of final goods, the emerging constellation of prices coordinates the various uses of resources and result in a coherent structure of production.

The essential instrument used by entrepreneurs in deciding upon the allocation of resources is monetary calculation. If their undertaking ends with a profit, then it means that resources were brought in line with consumers' needs. If the result is a loss, then inputs were diverted from their optimal employment and wasted into less important production processes. Investors and producers are stimulated to coordinate their businesses in order to respond to consumption demand. On a free market, production is rational and coherent, always subordinated to consumers' wishes.

Besides adopting an inadequate perspective on coordination, the market failure argument is unfeasible on its own grounds. In the next sections we explore in more detail some of its shortcomings. ${ }^{14}$

\subsection{The fallacy of coordination failure}

Rodriguez-Clare (2005, p. 4) starts his difficult way into the externalities argument by maintaining that "investment by one firm can have a positive effect on the profitability of investment by other firms, because higher investment gives rise to an increase in aggregate demand, which under economies of scale increases profitability of investment elsewhere in the economy". ${ }^{15}$ Yet why does investment itself enhance the profitability of all the other projects? At a closer look, it seems obvious that a particular

\footnotetext{
${ }^{13}$ An excellent description of the coordinative property of the market process can be found in Salerno (1991).

${ }^{14}$ We prefer to let aside the general weaknesses of the theory of externalities and public goods - which have been comprehensively analyzed by Block (1983), Hoppe (1989), Hummel (1990) and Holcombe (1997) - and focus instead on the particular case of coordination externalities.

${ }^{15}$ Yehoue (2005, p. 5) advances a similar argument.
} 
investment can have a negative, as well as a positive impact on other businesses. For example, the decision to build a bridge will promote road transportation but will necessarily undermine shipping businesses. It is not clear how an investment is good for society simply because it has beneficial implications on certain other entrepreneurial ventures.

Suppose that I am contemplating the possibility of building a fancy restaurant. Following Rodrik and Rodriguez-Clare, there are multiple equilibria. On the one hand, if I intend to locate my restaurant in the middle of a future poor neighbourhood, there are few chances that the restaurant will operate profitable. On the other hand, if I intend to situate my business in what is going to become a rich residential area, then probably it will attract many customers and the restaurant will prove a good investment. Obviously, in the latter situation, the restaurant will integrate successfully in the community; my investment in opening the restaurant will be consistent with the potential customers' decision to inhabit the same region. But, as the authors object, one can never be sure that this (good) equilibrium will actually occur, because potential customers do not know about my intention to build the restaurant, and, in turn, I do not know about how many of them intend to live in my neighbourhood. Cautious individuals may choose not move in, even though in the opposite case all of us would be better of and coordination achieved. So, why not convince the government to make the rich people move in the neighbourhood? Thus, coordination will be much easier to accomplish! The fact that nobody will find this idea reasonable is sufficient proof that the coordination failure argument proves far too much. In addition, the argument is silent about the fate of the individuals who actually live in my neighbourhood. When potential restaurant's customers are moved in, the present inhabitants are moved out. It is clear that this dislocation creates its own problems. But the advocates of state intervention overlook the discoordination resulted from this forced coordination.

Another point in the coordination failure argument is that coordination is costly. As Rodriguez-Clare (2005, p. 6) explains:

"One can think of a similar story to the one above, where coordination failures arise between workers thinking about investing in training and firms thinking about investing in technologies that require 
trained workers $[\ldots]$ Although a firm can contract with a worker so that they both invest in training and technology, and split the realized surplus, a problem arises because of the risk of separation. At that point, the firm would have to look for a trained worker, and the trained worker has to look for a job in a firm with modern technology. Given search costs, however, there is a risk that a productive match will not materialize, in which case firms and workers will have lost their investment."

The thesis that search costs undermines entrepreneurial coordination is misleading. There is no such thing as cost-free action. Search costs, like transportation costs or labor costs are economic costs which must be taken into account before deciding upon the allocation of resources. The fact that the height of search costs discourages some action is no more relevant that the fact that high transportation costs prevents a doctor from selling his services to a distant customer. If we pursue the argument to its logical conclusion, we will maintain that this is a good reason for state subsidization of the doctor's distant activity. But this is hardly acceptable. Therefore, it is obvious that one cannot derive any sound conclusion by comparing real world situations with the (perfect competition-based) model of Rodrik, where search is costless.

Further, search costs cannot be eliminated through state action, they can only be transferred onto other people. The government has to incur itself some search costs (associated with the implementation of cluster development strategies), and covers them through taxation. A natural question then is why are these costs more important than taxation? In the absence of a scientific answer, the sensible economist is encouraged to regard with caution the enthusiastic claims of coordination failure theorists and clusters' advocates. ${ }^{16}$

Considerations about the confusing nature of coordination failure arguments represent, however, only part of the story in the critique of modern development policy. We will turn now to the flaws in the case for clustering initiatives.

\subsection{The irrelevance of cluster concept}

\footnotetext{
${ }^{16}$ Indeed, in their imaginative scenarios of cluster development strategies development economists seem to rely on little more than statist presupositions and popular dogma about market failure.
} 
Let us focus first on the (lack of) significance of the cluster notion. Clusters are often seen as successful attempts to overcome coordination failures. According to Porter (1998, p. 226), "a cluster is a form of network that occurs within a geographical location, in which the proximity of firms and institutions ensures certain forms of commonality and increases the frequency and impact of interactions". From the very beginning, it is important to note the vagueness of this definition. As Martin and Sunley (2003, p. 10) emphasize,

"the obvious problem raised by these cluster definitions is the lack of clear boundaries, both industrial and geographical. At what level of industrial aggregation should a cluster be defined, and what range of related or associated industries and activities should be included? How strong do the linkages between firms have to be? How economically specialized does a local concentration of firms have to be to constitute a cluster? [...] At what spatial scale, and over what geographical range, do clustering processes (inter-firm linkages, knowledge spillovers, rivalry, business and social networks, and so on) operate? What spatial density of such firms and their interactions defines a cluster?"

The fuzzy meaning of the cluster concept has been referred to by various analysts as part of the intentional style of Porter, who seeks to provide policymakers with an argument for exercising interventionism. Porter's idea serves as basis for a redefinition of interventionist policy, following the obvious intellectual bankruptcy of the old (rude keynesian) macroeconomic policy and price interventionism. It provides the ground for a more refined, intellectual-appealing interventionism. ${ }^{17}$ The definitional elasticity of the cluster concept undermines the operationality of the theory while simultaneously making it an ideal tool for politicians. As Porter (1998, p. 102) himself admits, “drawing cluster boundaries is often a matter of degree, and involves a creative process informed by understanding the most important linkages and complementarities across industries and institutions to competition." This can only mean that the exact shape of clusters is related

\footnotetext{
${ }^{17}$ As Martin and Sunley (2003, p. 12) observe, the notion of cluster can be used in a variety of situations, "depending on what the aim of the exercise is, or the client or policymaker for whom the analysis is intended."
} 
to the discretionary choice of policymakers. Any attempt to circumscribe a group of related companies based upon a certain criterion runs the danger of overlooking important clusters; at the same time, too many firms might be selected and clusters can be loosely defined.

The policy recommendation concerning the promotion of clusters overlooks important economic insights. First of all, the formation of clusters enhances the productivity of individuals only if it springs naturally from the voluntary actions of the producers. To say that a higher agglomeration of firms (at the extreme, a single comprehensive cluster) encourages unconditionally the deepening of specialization, development of trade, promotes innovation and supports an increasing of economic growth, is to treat mechanistically human actions. It is true that cluster formation decreases some economic costs, because businessmen do not have to incur the same expenditures with transportation and search costs. But following similar reasoning, an extension of the number of producers on the market - that is, a deepening of the division of labor - increases search costs. Yet, as it is absurd to consider that agglomeration promotes society's welfare just because, by decreasing transportation and search costs, it simplifies trade and production, it is no more reasonable to assume that industrial clusters bring an increasing of welfare. Individuals do not wish unconditionally to avoid transaction costs by eliminating the distance among them. Beyond a certain level, increased agglomeration does not result in net positive external benefits, but in negative externalities. An important question for the entrepreneur deciding the location of its venture is whether agglomeration benefits are higher than congestion costs. The issue cannot be settled by an independent observer, because respective benefits and costs cannot be determined objectively. Therefore, the optimal density of investments can be discerned only by entrepreneurial judgement of market conditions.

It is difficult to prove empirically that clustering is by necessity beneficial. Rather, as history illustrates, people prefer to spread even if, as a consequence of their choice, the transportation expenses increase. On a free market, entrepreneurs will try to respond accurately to the demands of their customers, providing goods in the locations preferred by the public. Therefore, only on a free market would it be possible to discover what is the optimal size or the proper shape of a firm or cluster. Since political action is not a 
substitute for voluntary cooperation, the merits of a discretionary intervention on the organization of production are highly questionable.

Territorial industrial agglomerations spring from entrepreneurs' undertakings. In other words, the characteristics of a cluster are the outcome of speculative actions. Consequently, not all clusters spur the competitiveness of their members. There are examples of cluster failures. ${ }^{18}$ Businesses cluster together when entrepreneurs deem this decision to have a positive impact on their profits. In the opposite the case, industries will decide to remove their production units to new places. A number of factors can explain the decision of companies to disband a cluster: traffic congestion, increase in the price of land or labor, technological isomorphism and the risk of over-specialization (Martin and Sunley 2003, p. 27). Put it shortly, "Clusters dissolve when costs become too high for industries to remain competitive" (Buss 1999, p. 368). In fact, the point that clusters do not necessarily increase the competitiveness of member firms is acknowledged by Porter himself, when he states: "When a cluster shares a uniform approach to competing, a sort of groupthink often reinforces old behaviors, suppresses new ideas, and creates rigidities that prevent adoption of improvements. Clusters also might not support truly radical innovation, which tends to invalidate the existing pools of talent, information, suppliers, and infrastructure. In these circumstances, a cluster participant....might suffer from greater barriers to perceiving the need to change..." (Porter 2000, p. 24, emphasis added.)

Clusters represent a form of industrial organization. It results from the uncessant attempt of entrepreneurs to arrange the structure of production so as to fulfill to the best extent possible the consumers' demands. Therefore, clusters are specific consequences of entrepreneurial ventures. ${ }^{19}$ As Feldman and Francis (2004, p. 130) observes, "the process of cluster development is neither linear nor fully predictable." The actual statistical image of a cluster reflects past businesses relationships and cannot serve as an indication of its

\footnotetext{
${ }^{18}$ See, for example, Chapman (2005). The reluctance to accept this perspective has serious practical consequences. As Bresnahan, Gambardella and Saxenian (2001, p. 7) note, "Many governments have made the analytical error of focusing far too much on the second aspect of external effects, and have viewed clusters of innovative activity as no more than a ticket to producer rents. This has provided the intellectual foundation for largely failed policies that attempt to jump-start growth in clusters by directive policy."

19 "Clustering is the result of entrepreneurial activity and is driven by the production of valued goods to seize profits. Governments cannot therefore supersede the market in the creation of clusters." (Desrochers and Sautet 2004, p. 238-239).
} 
future evolution. Government meddling with clusters is tantamount to interference in the entrepreneurial process by which resources are directed toward the fulfillment of the market participants' most urgent needs. It introduces artificial incentives that weaken the inherent coordinative quality of market incentives. ${ }^{20}$

Instead of reasoning in terms of "externalities" and "market failure", it is time for mainstream economists to realize that government is a substantive source of entrepreneurial discoordination. Through its trade policy - imposing different regulations and technical specifications, customs duties, quotas, voluntary export adjustments immigration laws, regulations concerning capital movement etc., the state is the only source of barriers for trade and economic (inter-regional) integration. In addition, industries' decisions concerning localization are also indirectly influenced by the government policy. State intervention is the object of individuals' anticipations, and it consequently changes the behavior of economic agents. If market participants expect a change in government policy, they will act in order to capture all the benefits and minimize the losses arising from that policy. For example, apparent lack of delocalization to improve the coordination of production is due to the expected shift of industrial policy. Therefore, far from being an exogenous variable, geographical disparities in the production structure should be considered as dependent on the political institutions governing the market process.

Another problem, perhaps more relevant for those economists accepting an innocent view of the state, because it explodes any practical relevance of the Porterian theory, arises because of the lack of any independent criteria to establish the proper shape of a cluster. The complementarity criterion put forward by the argument is not permanent, but changes over time. ${ }^{21}$ Technical progress provides new methods of combination among inputs and new complementarity patterns between production processes. Changes in individual preferences cause the relative prices of goods to vary permanently and this, in turn, increases or reduces the number of closed substitutes and complements for any given good. The concrete specialization of economic units is also determined by the actual array of relative prices. All this makes the attempt to

\footnotetext{
${ }^{20}$ Besides this, Barkley and Henry (1997) discusses several shortcomings of cluster development strategies.

${ }^{21}$ Porter (1998) admits this explicitly: "Clusters continually evolve as new companies and industries emerge or decline and as local institutions develop and change."
} 
circumscribe economic clusters illusory, because these industrial districts continually change. Therefore, correcting market coordination failures through clusters' development appears more as a recipe for chaos than a serious suggestion for a new industrial policy.

\section{Coordination and government intervention}

Leaving aside the criticism outlined above, it is interesting to analyze the details of development economists' strategy for government intervention.

First, consider the importance many economists attach to the evaluation of investment projects by independent collective bodies. It is become a custom for governments to use boards of independent experts to evaluate the merits of different business plans competing for public financing. Since development economists are so optimistic about the quality of such an institutional invention, the natural question that arises is: why not extend the "mechanism" to all businesses and investment projects? The government could tax away individuals' income and then redistribute it according to the authoritative views of the "panel of experts". Development economists seem not to notice how much their argument can prove.

One of the merits of the proposed scheme is transparency. Unlike the early vision of industrial policy which saw in the policymaker a benevolent social planner, the new development economics attempts to incorporate (albeit in an unsatisfactorily manner) the public choice insights about the nature of the political process. It emphasizes the importance of transparency as a standard for assessing state industrial initiatives. But why is transparency so important about government policy? Freezing commodities' prices or wages is a very transparent political measure. Yet at the present, it is far from being advocated by policymakers, because its harmful effects have become widely understood. ${ }^{22}$ This example shows that transparency is not a proper criterion to evaluate policy initiatives.

Despite their efforts to differentiate their proposal from the older industrial policy, the distinctions authors like Porter, Rodrik and Rodriguez-Clare introduce are nothing

\footnotetext{
${ }^{22}$ One could argue that government is always tempted to choose the least transparent measures available at the moment.
} 
more than rhetorical innovations. As a number of writers have aptly noted, ${ }^{23}$ the new sort of interventionism amounts to nothing more than picking winners. In a sense, this new political activism can incur even higher costs on society than previous attempts to engineer development. Since picking clusters means that policymakers should target groups of companies or industries, rather than specific businesses, the magnitude of potential failures increases considerably. If government's privileges fail to promote growth, than the outcome will be not punctual bankruptcies as in the past, but the occurrence of clusters of losses. ${ }^{24}$

According to Rodrik, the policy of correcting coordination failures need not consist in subsidization. As he explains, "it is the logic of coordination failures that once the simultaneous investments are made all of them end up profitable. Therefore none of the investors needs to be subsidized ex post, unless there is an additional reason (i.e., a non-pecuniary externality) that such subsidization is required." What is needed in order to induce entrepreneurs to start complementary investments is an "ex-ante subsidy", consisting for example in a implicit bail-out or an investment guarantee. Put it this way, the "new" industrial policy seems to be apparently immune against much of the virus of excessive public spending, deficits and malinvestment usually associated with government activity. But it is still exposed to corruption, rent seeking and moral hazard that eventually have the same distorting effect on the production structure.

There is still a huge gap between the actual arguments about the necessity of solving coordination failure through government-sponsored mechanisms and the requirements these arguments have to fulfill in order to be considered scientifically valid. As Beaulier and Subrick (2006) show, development economists have to acknowledge the fact that social planners are neither benevolent nor omniscient. However, the free market cannot be defended successfully by pointing out that policymakers do not posses enough information to allocate resources optimally, or by emphasizing the corruptive nature of the state. Perhaps government bureaucrats are both smarter (and better informed) than private entrepreneurs, and well intended. This hypothesis is, of course, completely

\footnotetext{
${ }^{23}$ See, for example, Desrochers and Sautet (2004), Buss (1999a).

${ }^{24}$ Desrochers (2004, p. 239) notes that it is not clear whether cluster-based regional development policy is beneficial for the future of these regions, given that "diversified local economies are more stable than
} 
imaginary, but it should not be dismissed only because it is empirically irrelevant. Government interventionism has to be criticized granted that policymakers are morally and intellectually the best members of society.

In spite of its new clothes, government interventionism has no more solid foundation that it ever had. The problem with industrial policy is deeper than most of its critics admit. Starting with Mises (1990), a large Austrian literature argued that in the absence of private property, money prices cannot emerge and economic calculation is impossible. At the limit, in a socialist commonwealth, the central planner has no rational way to decide whether to shift resources from project A to project B. Its intervention is arbitrary because cannot be subjected to the profit and loss test, as private activities are. As Rothbard (1962, p. 825) observed, any puctual decision to socialize investment introduces an island of calculational chaos in the market economy. Promises to bail-out entrepreneurs in case they fail to operate profitably, as Rodrik indicates, amount in a de facto socialization of private investments.

The advocates of industrial policy think government can act as private businesses do, using the profit and loss criterion to decide between different investment projects. At this point, Rodriguez-Clare (2005, p. 28) believes that, "at least in principle, one could calculate a social return for such an investment. With limited resources, the obvious approach would be to invest in the proposals that entail the highest social returns. The problem, of course, is that calculating such social returns is very difficult. One (perhaps limited) way to interpret prospective studies is as a way to facilitate this calculation." Here, the author (to his own merit) touches the real problem of industrial policy. The state is not an entrepreneur, so it is not in position to "interpret" prospective studies the same way private individuals do. ${ }^{25}$ More precisely, policymakers cannot calculate as private entrepreneurs do. Therefore, their decision is merely a "leap into darkness".

\section{Conclusion}

highly specialized regions that are more prone to abrupt decline if their main line of business is supplanted by competitors located elsewhere or if new and better substitute products are manufactured elsewhere."

${ }^{25}$ Rather, as Buss (1999b, p. 367) says, "there are only individual or group interests that use public authority to their benefit, often at the expense of others." 
In this paper I have tried to prove that the coordination failure argument does not provide a solid ground for a reshaping of the industrial policy both because of its lack of sound theoretical foundation, and because of its empirical irrelevance. We have seen that at the root of the argument is a misunderstanding of the role of entrepreneurs in industrial organization. Spatial localization is one dimension of the entrepreneurial action. Although the lack of conceptual precision makes the case for industrial policy appealing, coordination and cluster analysis cannot be used to improve the allocation of resources above the level reached on a free market. There is no recipe for clusters. Cluster-based targeting is so widely practiced not because of scientific merit, but for political reasons. Last, but not in the least, the rationale for clustering initiatives fails to address properly the information, incentives and calculation problems which plague economic policy in general. Thus, numerous pitfalls prevent the "new" industrial policy to be considered a refined ingredient of development economics.

\section{References}

Anderson, David E. 2005. “The Spatial Nature of Entrepreneurship.” The Quarterly Journal of Austrian Economics 8(2): 21-34.

Andersson, Thomas, Serger, Sylvia, S., Sörvik, Jens and Hansson, Emily W. 2004. The Cluster Policies Whitebook. International Organisation for Knowledge Economy and Enterprise Development. Malmö

Beaulier, Scott A. and Subrick, Robert J. 2006. "Poverty Traps and the Robust Political Economy of Development Assistance." The Review of Austrian Economics 19(2/3): 217-226.

Bergman, Edward M. and Feser, Edward J. 1999. "Industrial and Regional Clusters: Concepts and Comparative Applications.” In: Jackson, R. W. (Ed.) The Web Book of Regional Science, Regional Research Institute, West Virginia University, http://www.rri.wvu.edu/WebBook/Bergman-Feser/contents.htm.

Block, Walter. 1983. "Public Goods and Externalities: The Case of Roads". Journal of Libertarian Studies 7(1): 1-34

Bresnahan, Timothy, Gambardella, Alfonso and Saxennian, AnnaLee. 2001. “'Old 
Economy' Inputs for 'New Economy' Outcomes: Cluster Formation in the New Sillicon Valleys". Industrial and Corporate Change 10(4): 835-860

Buss, Terry F. 1999a. “The Case Against Targeted Industry Strategies”. Economic Development Quarterly 13(4): 339-356

Buss, Terry F. 1999b. “To Target or Not to Target, That's the Question: A Response to Wiewel and Finkle". Economic Development Quarterly 13(4): 365-370

Chapman, Keith. 2005. 'From 'Growth Centre' to 'Cluster': Restructuring, Regional Development, and the Teeside Chemical Indutry." Environment and Planning A 37: 597-615.

Danson, Michael and Whittam, Geoff. 1999. Regional Governance, Institutions and Development. In: Jackson, R. W. (Ed.) The Web Book of Regional Science, Regional Research Institute, West Virginia University http://www.rri.wvu.edu/WebBook/Danson/chapterfive.htm

Desrochers, Pierre. 2001. "Geographical Proximity and the Transmission of Tacit Knowledge." Review of Austrian Economics14 (1): 25-46.

Desrochers, Pierre and Sautet, Frédéric. 2004. "Cluster-Based Economic Strategy, Facilitation Policy and the Market Process". Review of Austrian Economics 17(2/3): 233-245

European Commission. 2002. Regional Clusters in Europe, Observatory of European SMEs, No. 3, Brussels.

European Commission. 2003. Final Report of the Expert Group on Enterprise Clusters and Networks, Brussels.

Feldmann, Maryann P., and Francis, Johanna. 2004. "Homegrown Solutions: Fostering Cluster Formation.” Economic Development Quarterly 18(2): 127-137

Feldmann, Maryann P., Francis, Johanna and Bercowitz, Janet. 2005. "Creating a Cluster While Building a Firm: Entrepreneurs and the Formation of Industrial Clusters." Regional Studies 39(1): 129-141

Ferris, Stephen and Gawande, Kishore 1998. "Coordination Failures and Government Policy: Evidence From Emerging Countries.” Carleton Economic Papers 3

Feser, Edward. 2002. "The Relevance of Clusters for Regional Innovation Policy.” White Paper prepared for the World Bank, Latin American and Caribbean Group. June 
Gordon, Ian R. and McCann, Philip. 2000. "Industrial Clusters: Complexes, Agglomeration and/or Social Networks?". Urban Studies 37(3): 513-532.

Hirschman, A.O. 1957. The Strategy of Economic Development, New Haven, CT: Yale University Press.

Hoff, Karla and Stiglitz, Joseph. 2001. "Modern Economic Theory and Development.” In Meier, G. and Stiglitz, J. E. eds. Frontiers of Development Economics: The Future in Perspective. New York: Oxford University Press, pp. 389-485.

Hoff, Karla. 2000. "Beyond Rosenstein-Rodan: The Modern Theory of Coordination Problems in Development." In Pleskovic, B. ed. Proceedings of the Annual World Bank Conference on Development Economics. Washington DC: World Bank

Holcombe, Randall G. 1997. "A Theory of the Theory of Public Goods". Review of Austrian Economics 10(1): 1-22

Hoppe, Hans-Hermann. 1989. A Theory of Socialism and Capitalism. Boston. Kluwer Howitt, Peter. "Coordination Failures". In Vane H. and Snowdon B. eds. An Encyclopaedia of Macroeconomics. Edward Elgar

Hummel, Jeffrey R. 1990. "National Goods Versus Public Goods: Defense. Disarmament. and Free Riders". Review of Austrian Economics 4: 88-122

IRE. 2005. An overview of Cluster Policies and Clusters in the New Member States of the European Union. Innovating Regions in Europe. http://www.innovatingregions.org

Ketels, Christian H. M. 2005. "European Clusters". The Competitiveness Institute Marshall, David. 1998. "Understanding the Asian crisis: Systemic Risk as Coordination Failure”. Economic Perspectives:13-28. Federal Reserve Bank of Chicago

Maskell, Peter and Kebir, Leila. 2005. What qualifies as a cluster theory?. DRUID Working Paper no. 05-09

Martin, Ron and Sunley, Peter. 2003. "Deconstructing Clusters: Chaotic Concept or Policy Panacea?”. Journal of Economic Geography 3: 5-35

Mises, Ludwig von. 1998. Human Action. Scholar's edition. Auburn. Ala.: Ludwig von Mises Institute

Mises, Ludwig von. 1990. Economic Calculation in the Socialist Commonwealth. Auburn. Ludwig von Mises Institute 
Nadvi Khalid and Barrientos Stephanie. 2004. Industrial Clusters and Poverty Reduction. Towards a methodology for poverty and social impact assessment of cluster development initiatives. UNIDO. Vienna

Sölvell, Örjan, Ketels, Christian H. and Lindqvist, Göran. 2003. The Cluster Initiative Greenbook, The Competitiveness Institute/Vinnova: Gothenburg.

Porter, Michael. 2000. "Location, Competition, and Economic Development: Local Clusters in a Global Economy." Economic Development Quarterly, 14(1): 15-34

Porter, Michael. 1998a. On Competition. Harvard University Press: Cambridge

Porter, Michael. 1998b. "Clusters and the New Economics of Competition" Harvard Business Review 76(6): 77-90

Porter, Michael. 1990. The Competitive Advantage of Nations. The Free Press. New York.

Rodriguez-Clare, Andres. 2005a. "Coordination Failures, Clusters and Microeconomic Interventions.” Inter-American development Bank Working Paper. June

Rodriguez-Clare, Andres. 2005b. "Clusters and Comparative Advantage: Implications for Industrial Policy." Inter-American development Bank Working Paper 523. December

Rodrik, Dani. 2004. "Industrial Policy for the Twenty-First Century". Working Paper. October. Harvard University

Rosenstein-Rodan, Paul. 1943. "Problems of Industrialization of Eastern and Southeastern Europe.” Economic Journal 53(210-211) June-September: 202-211.

Rothbard, Murray. 1962. Man, Economy and State: A Treatise on Economics. Princeton, D. Van Nostrand

Salerno, Joseph T. 1991. "The Concept of Coordination in Austrian Macroeconomics". In Champions of Freedom: Austrian Economics: Perspectives on the Past and Prospects for the Future. Hillsdale. Hillsdale College Press

Sautet, Frédéric. 2002. Economic Transformation, The Pretence of Knowledge and the Process of Entrepreneurial Competition. New Zealand Treasury Discussion Paper http://www.treasury.govt.nz/et/\#9

UNCTAD. 2002. Partnerships and Networking in Science and Technology for Development. United Nations Conference on Trade and Development, 
Technology for Development Series, Geneva.

http://www.kiet.re.kr/files/econo/20020325-partner.pdf.

UNIDO. 2001. Development of Clusters and Networks of SMEs: The UNIDO

Programme. United Nations Industrial Development Organization, Vienna.

Yehoue, Etienne B. 2005. "Clusters as a Driving Engine for FDI". IMF Working Paper $05 / 93$ 